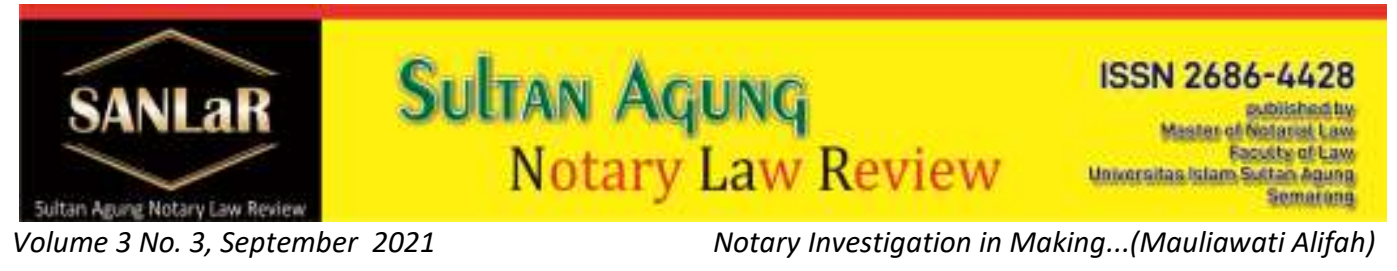

\title{
Notary Investigation in Making Copies of CV's Deed Establishment Which Different Numbers in Minuta
}

\author{
Mauliawati Alifah*) \\ $\left.{ }^{*}\right)$ Faculty of Law, Universitas Islam Sultan Agung (UNISSULA) Semarang, E-mail: \\ maulia.affandy@gmail.com
}

\begin{abstract}
CV deed whose minute deed number is different from the copy of the deed. The existence of a Notary who is summoned and examined by the Police is related to the tasks carried out by a Notary, namely: making a copy of the CV's deed of establishment which turns out to be a different number from the minutes of the deed. Meanwhile, the notary concerned does not believe that the copy of the deed has a different number with the minutes of the deed. Notaries have the responsibility in terms of discrepancies between the Copies of the Deed and the Minutes of the Deed, which have been regulated both in the Act and in the Notary Code of Ethics. This study uses normative juridical. Normative juridical research examines the factual implementation or implementation of positive legal provisions (laws) and contracts in each particular legal event. The results of this study are 1) The role of the investigator against the Notary who makes a copy of the deed, Investigators, Public Prosecutors, and Judges are only allowed to take photocopies of the minutes of the deed and/or letters attached to the minutes of the deed or the protocol of the notary in the notary's storage, as long as for the interest of the judicial process and has obtained the approval of the Notary Honorary Council; 2) Efforts that can be made by a notary in the event of a typo contained in the minutes of the deed whose copy has been issued are basically casuistic in nature, for example the Deed of Establishment of a Limited Liability Company (CV), there is a typo.
\end{abstract}

Keywords: Notary; Investigation; Copies; Deeds; Minuta.

\section{Introduction}

Notaries as public officials as well as a profession, their position is very important in helping to create legal certainty for the community. In carrying out his position, he is obliged to carry out his duties with full discipline, professionalism 
and his moral integrity must not be doubted. ${ }^{1} \mathrm{~A}$ Notary is required to prioritize the attitude of trustworthiness, honesty, thoroughness, independence, impartiality, and guaranteeing the preservation of the interests of related parties in carrying out legal actions as stated in Article 16 paragraph (1) letter of the Notary Position Law and other obligations are to follow the Notary protocol by making Minutes of Deed which is then stored, this is stated in Article 16 paragraph (1) letter b. In addition, the Notary can also be held responsible for his actions in connection with the work in making the deed, this makes the scope of the notary's responsibility divided including the material truth of the deed he made. $^{2}$ The responsibilities of a notary as a public official related to material truth are divided into 4 (four) points, namely: ${ }^{3}$

a. The civil liability of the notary to the material truth in the deed he made

b. The notary's criminal responsibility for the material truth in the deed he made

c. The notary's responsibility based on the Notary Position Regulations on the material truth in the deed he made

d. The responsibilities of a notary in carrying out his duties are based on a notary code of ethics.

The notary should in making the deed must ensure the prevention of legal problems through the authentic deed he made as the most perfect evidence in court. What happens if the notary becomes a source of problems for the law due to the credibility of the authentic deed he made is questioned by the public. Act No. 2 of 2014 concerning Notary Positions, hereinafter referred to as the Notary Position Act further emphasizes the important position of the notary as a public official who provides legal certainty through the authentic deed he makes. Through the deed he made, the notary must be able to provide legal certainty to the public who use notary services. ${ }^{4}$

There are two kinds of authentic deeds made by a notary, namely an authentic deed made by an official or what is called a relaas deed and an authentic deed made before an official containing the parties or what is called a party deed or a party deed. ${ }^{5}$ The deed made by a notary can be a deed that contains "relaxation" or describes authentically an action taken or a situation that is seen or witnessed by the maker of the deed, namely the notary himself, in carrying out his position as a notary. However, the notary deed can also contain a "story" of what

\footnotetext{
${ }^{1}$ A.Kohar, Notaris Dalam Praktek Hukum, Alumni, Bandung, 1983, p. 3

${ }^{2}$ Abdul Ghofur Anshori, Lembaga Kenotariatan Indonesia Perspektif Hukum dan Etika, UII Press, Yogyakarta, 2009, p. 39

${ }^{3}$ lbid,p. 34

${ }^{4}$ H. Salim \& H. Abdullah, Perancangan dan MOU, Sinar Grafika, Jakarta, 2007, p. 101

${ }^{5}$ Nico, Tanggung Jawab Notaris Selaku Pejabat Umum, Centre For Documentation and Studies Bussiness Law, Yogyakarta, 2003, p.25.
} 
happened because of the actions committed by other parties before the notary. This means that what is explained or told by another party to the Notary in carrying out his position and for which purposes the other party deliberately comes before the Notary and gives the information or performs the act before the Notary, so that the statement or act is confirmed by the Notary in an authentic deed. Such a deed is called a deed made "in front of" a notary. ${ }^{6}$

Notaries in carrying out the obligations of making a deed sometimes occur negligence so that they have to deal with legal cases. One example of this negligence occurred in a Notary in the city of Semarang who made a CV deed with a different minuta deed number from the copy of the deed. The existence of a Notary who is summoned and examined by the Police is related to the tasks carried out by a Notary, namely: making a copy of the CV's deed of establishment which turns out to be a different number from the minutes of the deed. Meanwhile, the notary concerned does not believe that the copy of the deed has a different number with the minutes of the deed. Notaries have the responsibility in the event of discrepancies between the Copies of the Deed and the Minutes of the Deed, which have been regulated both in the Law and the Notary Code of Ethics. ${ }^{7}$

Can be formulated in this research: 1) To find out and analyze the role of the investigator against the Notary who makes a copy of the deed of establishment Limited Liability Company (CV) whose number is different from the minutes of the deed in the construction of legal protection. 2) To find out and analyze the position of the copy of the deed whose number is different from the minutes of the deed in the construction of legal certainty.

\section{Research Methods}

This research uses the type of normative juridical research, this research examine the implementation or implementation of positive legal provisions (laws) and contracts factually in every particular legal event that occurs in society in order to achieve the goals that have been determined. ${ }^{8}$ The study aims to ascertain whether the results of the application of legal events in concreto are in accordance with or not in accordance with the provisions of the law.

\footnotetext{
${ }^{6}$ G.H.S Lumban Tobing, Peraturan Jabatan Notaris, Erlangga, Jakarta, 1999, p.2.

7 R. Soegondo Notodisorjo, Hukum Notariat di Indonesia (Suatu Penjelasan), Raja Grafindo Persada, Jakarta, 1993, p. 55.

${ }^{8}$ Muhammad, Abdulkadir, Hukum dan Penelitian Hukum, Citra Aditya Bakti, Bandung, 2004, p. 134.
} 


\section{Results and Discussion}

3.1. The Role of Investigators Against Notaries Who Make Copies of the Deed of Establishment Limited Liability Company (CV) whose number is different from the Minutes of Deed in Legal Protection Construction

Notaries are authorized to make authentic deeds regarding all actions, agreements, and provisions required by laws and/or regulations which is desired by the interested party to be stated in an authentic deed, guaranteeing the certainty of the date of making the deed, keeping the deed, providing grosse, a copy and an excerpt of the deed, all of this as long as the making of the deed is not assigned or excluded to another official or other person as determined by the Constitution. ${ }^{9}$

An authentic deed is a deed which, in the form determined by law, is made by or before public officials in power for that purpose at the place where the deed was made.

Based on the above definition, the deed made by or before a Notary is an authentic deed. An authentic deed is evidence that has perfect evidentiary power, so that with the issuance of an authentic deed for certain legal actions, if in the future there is a dispute over the things recorded in the deed, the existence of the authentic deed will be very decisive for the disputed matter by the parties, because the decision issued by the judge is highly dependent on the evidence submitted by each disputing party before the court session. ${ }^{10}$

Notary is a very respectable profession in the eyes of the public with its specific authority in making authentic deeds, in simple terms it can be said that a notary is a public official who is authorized to make authentic deeds and has other authorities as stipulated in the law. In making these authentic deeds, a notary has understood and studied carefully according to the intentions of the parties facing him by referring to the Standard Operating Procedure (SOP) in making the intended authentic deed, so as to produce a product in the form of an authentic deed that is valid and in accordance with the wishes the parties.

However, in carrying out this authority, sometimes a notary, either intentionally or unintentionally, commits several acts against the law that lead to a criminal act. In a criminal event that is suspected to involve the notary profession, the investigator will examine more deeply about the involvement of the notary, whether it is only as a witness, or has it led to being a "dader" or the culprit. For

\footnotetext{
${ }^{9}$ Tan Thong Kie, Studi Notariat dan Serba-serbi Praktek Notaris, Buku 1, Ichtiar Baru Van Hoeve, Jakarta, 2000, p. 7.

${ }^{10}$ Viktor M. Situmorang dan Cormentya Sitanggang, Grosse Akta dalam Pembukuan dan Eksekusi, Rineka Cipta, Jakarta, 1993, p. 13
} 
this reason, investigators will certainly see the extent of the "role" of the notary in the criminal incident. Furthermore, the investigator makes the anatomy of the case according to its chronological position and legal facts, along with supporting documents as evidence.

In criminal law, there are only 5 (five) valid pieces of evidence, namely witness statements, expert statements, letters, instructions, and statements from the defendant. From the facts above which are assembled into one and supported by the statements of the witnesses accompanied by evidence, the real construction of the case in question will be drawn by mapping out the roles of each of the parties involved. It is this role that can determine whether a notary is involved or not in the criminal incident, so it is the main task of investigators to continue to explore the role of each party ${ }^{11}$.

This role can only be explored from whether there is evil intention (mensrea) from the perpetrator and whether the evil intention has been realized into an evil act (actus reus), then what is called an unlawful act (wederechtelijk). So that the criminal act can be formulated as having violated a formal offense (a prohibited act) or a material offense, which apart from the prohibited act being carried out, there must still be consequences arising from that act, then it is said that the crime has occurred completely (voltooid) ${ }^{12}$.

Calling a notary as a "Witness" is something that is commonly experienced by most people, it will not affect his reputation as a notary. However, if a notary is called a "suspect", it will automatically affect his performance as well as his reputation.

Meanwhile, if the status of the notary is a witness, the notary may not be sworn in. Unless there is sufficient reason, the notary concerned may not attend the trial. In the memorandum of understanding, the notary and PPAT also requested that they only be examined by investigators, not assistant investigators. Even if it will be examined by an assistant investigator, the reason must be proper and reasonable. There is also a clause regarding a notary suspected of committing a crime in relation to the deed he made, in accordance with Article 54 of the Criminal Procedure Code, in which the notary has the right to obtain legal assistance. A notary who is a suspect has the right to be accompanied by INI administrators when questioned by the police. If during the examination it is not

\footnotetext{
${ }^{11}$ A Chuasanga, Ong Argo Victoria. (2019). Legal Principles Under Criminal Law in Indonesia Dan Thailand, Jurnal Daulat Hukum, Vol 2, No 1 (2019) http://jurnal.unissula.ac.id/index.php/RH/article/view/4218

12 Deen, Thaufiq., Ong Argo Victoria \& Sumain. (2018). Public Notary Services In Malaysia. JURNAL AKTA: Vol. 5, No. 4, 1017-1026. Retrieved from http://jurnal.unissula.ac.id/index.php/akta/article/view/4135
} 
proven that there is a criminal element, the investigator is obliged to issue SP3 as soon as possible. In the case of a confiscation process against a notary protocol ${ }^{13}$.

The procedure for taking the minutes of deed or Notary Protocol according to Syafroni, SH, a former MPD member of Majalengka Regency, West Java, refers to Article 8 of the Minister of Law and Human Rights No. M.03.HT.03.10 of 2007 which stipulates that investigators for the purposes of the judicial process may take the Minutes of Deed and or letters attached to the Minutes of Deed or the Notary Protocol in the Notary's depository, by asking the Notary concerned to bring the Minutes of Deed and/or the letters attached to the Minutes of Deed or Notary Protocol in the Notary's depository by submitting a written application to the MPD containing the reasons; a copy of the application is submitted to the notary concerned. The procedure also applies to taking a photocopy of the Minutes of the Notary Deed based on Article 2 of the Minister of Law and Human Rights No. M.03.HT.03.10 of 2007.

The MPD's approval for taking a photocopy of the Minutes of Deed and Minutes of Deed is given after the MPD has heard the information from the Notary concerned (Article 4 in conjunction with Article 10 of the Minister of Law and Human Rights No. M.03.HT.03.10 of 2007). MPD is obliged to give approval or not to give written approval within a period of no later than 14 (working) days from the date of receipt of the said application; and if the time period is exceeded MPD is deemed to have agreed (Article 6 in conjunction with Article 12 of the Minister of Law and Human Rights Number M.03.HT.03.10 of 2007).

Provision of a photocopy of the Minutes of Deed to the Investigator accompanied by an official report of the handover (Article 7 Permenkumham No.M.03.HT.03.10 of 2007). As for the Minutes of Deed, the Investigator can only ask the Notary to bring the Minutes of Deed to be examined at the Forensic Laboratory Center regarding the validity of the signature and/or thumbprint on the specified day; and if the examination has not been completed, the Notary will bring back the Minutes of Deed to be re-examined on the specified day; and when the examination has been completed, the Minutes of Deed are handed back to the Notary concerned (Article 13 of the Minister of Law and Human Rights No. M.03.HT.03.10 of 2007).

The provisions of Article 16 paragraph (1) letter 1 of Act No. 2 of 2002 concerning the Indonesian National Police (Polri) authorize the National Police as

\footnotetext{
${ }^{13}$ Ong Argo Victoria, (2018) Waqf Al-Nuqūd In Indonesia (In Law Perspective), Jurnal Pembaharuan Hukum Vol 5, No 1 Universitas Sultan Agung, http://jurnal.unissula.ac.id/index.php/PH/article/view/2999 and Sukarmi, S., \& Victoria, A. (2018). Cash Waqf in Sustaining Of Indonesian Society "In Legal \&amp; Economic Perspective". AL-ITQAN: JOURNAL OF ISLAMIC SCIENCES AND COMPARATIVE STUDIES, 2(1), 8397. https://doi.org/10.31436/al-itqan.v2i1.43
} 
investigators to take responsible actions according to law. The provisions of Article 6 paragraph (2) of the Police Law, stipulates that what is meant by responsible actions according to law are:

a) Not against a rule of law;

b) In accordance with the legal obligation that requires the action to be carried out;

c) Must be appropriate, reasonable, and included in the investigator's office environment;

d) Appropriate consideration based on compelling circumstances;

e) Respect human rights.

The actions mentioned above must be carried out by investigators in every investigation process. During the investigation process, there are several parties who will be questioned, including witnesses and suspects. What is meant by witnesses in criminal cases relating to the formal aspects of the notary deed, the investigators, public prosecutors and judges will include the notary having taken legal action:

a) Making fake/forged letters and using fake/forged letters (Article 263 paragraph (1), (2) of the Criminal Code).

b) Doing forgery (Article 264 of the Criminal Code).

c) Ordered to include false information in an authentic deed (Article 266 of the Criminal Code).

d) Doing, ordering to do, participating in doing (Article 55 in conjunction with Article 263 paragraphs (1) and (2) or Article 264 or 266 of the Criminal Code).

e) Assist in making fake/falsified documents (Article 56 paragraphs (1) and (2) in conjunction with Article 263 paragraph (1) and (2) or Article 264 or 266 of the Criminal Code).

Examination of a notary as a suspect or defendant must be based on the procedure for making a notary deed, namely:

a) Conduct an introduction to the appearer, based on his/her identity shown to a notary.

b) Asking questions, then listening and paying close attention to the wishes or wishes of the parties (questioning and answering).

c) Examine the documentary evidence relating to the wishes or wishes of the parties.

d) Provide advice and create a deed framework to fulfill the wishes or wishes of the parties.

e) Fulfill all administrative techniques for making a notarial deed, such as reading, signing, providing copies, and filing for minutes. 
f) Perform other obligations related to the implementation of the duties of a notary public.

The examination/investigation procedure is an administrative procedure that must be followed to carry out an inspection activity in a series of Police actions, so that the examination carried out meets the administrative and juridical requirements. The investigation procedures include:

a) General procedure based on KUHAP (Book of Criminal Procedure Code);

b) Special procedures based on the laws that govern them.

The procedures for its implementation are as follows:

a) The investigator submits a letter to the Regional Supervisory Council stating for what purpose, whether to take a photocopy of the minutes of the deed and/or the letters attached to the minutes of the deed or the protocol of the notary in the notary's depository, or the need to summon a notary to attend the examination related to the minutes of the deed made or the notary protocol that is in the notary's storage.

b) The petition briefly explains what the case is and who the suspect is.

c) After obtaining approval, the Police investigators can take Police actions as stated in number 1 above.

The legal basis for summoning a notary is contained in Act No. 2 of 2014 concerning the Position of a Notary, particularly in Article 66, namely:

1) For the purposes of the judicial process, Investigators, Public Prosecutors, or Judges with the approval of the Notary Honorary Council are authorized to:

a) Take a photocopy of the minutes of the deed and/or the letters attached to the minutes of the deed or the protocol of the notary in the notary's depository; and

b) Calling the notary to attend the examination related to the deed he made or the notary protocol that is in the notary's storage.

c) Taking a photocopy of the minutes of the deed or letters as referred to in paragraph (1) letter a, an official report of the submission is made.

It is understood that the provisions contained herein are: 
a) Investigators, Public Prosecutors, and Judges are only allowed to take a photocopy of the minutes of the deed and/or letters attached to the minutes of the deed or the notary protocol in the notary's depository, as well as to summon the notary to be present in the examination related to the deed he made or the protocol of the notary who is in the possession. in storage, as long as it is for the purposes of the judicial process and has obtained the approval of the Notary Honorary Council;

b) Investigators, Public Prosecutors and Judges are not allowed to take the minutes of the deed and/or original documents attached to the minutes of the deed or the protocol of the notary in the notary's depository;

c) Summons of a notary by investigators, public prosecutors or judges to attend the examination of a case, whether civil, criminal or state administration/administration that are not related to the deed made or the protocol of the notary in the notary's depository, does not require approval from the Notary Honorary Council;

d) In the sense of a notary as stated in Article 66 of Act No. 2 of 2014 concerning Notary Positions, including Temporary Notary Officials, Substitute Notaries, and Special Substitute Notaries, both still carrying out their duties and have stopped;

e) For taking a photocopy of the minutes of the deed and/or documents as described above, an official report of the submission is made, however, this Law and its explanation do not provide an explanation of who is obliged to make and sign the minutes.

3.2. The position of the copy of the deed whose number is different from the minutes of the deed in the construction of legal certainty

Deed of Minutes of Correction is a notarial deed which is included in a special relaas deed (special verbal deed). It is said to be a special relaas deed because the deed can be made by a notary on his own initiative, without any request from interested parties. So, if the notary knows that in a minutes the deed that has been signed contains a typo, he can immediately correct the error, even without the assistance or approval of the parties, as long as the correction is in 
accordance with the reality that has occurred and does not exceed the authority of the notary. ${ }^{14}$

In the Deed of Minutes of Correction, the signature of the appearer is not mandatory. However, the Deed of Minutes of Correction must be signed by the witnesses.

After the Deed of Minutes of Correction is completed, based on Article 51 paragraph (2) of the UUJN, the notary is obliged to provide a note on the existence of such corrections in the minutes of the original deed by stating the date and number of the Deed of Minutes of Correction. What is meant by "original minutes of deed" is the minutes of the deed in which there are written errors and/or typographical errors. Furthermore, the notary shall submit a copy of the Deed of Minutes of Correction to the parties. ${ }^{15}$

Regulations regarding the correction of typos like this are a new thing in the UUJN. In it there is great authority for the notary to correct a typo in the minutes of the deed that has been signed. However, in the law there is no limitation or explanation of what is meant by a typo. The absence of such limits or explanations can eventually lead to various interpretations, including regarding what type of typo can be corrected by making a Deed of Minutes of Correction.

To interpret what kind of typos can be corrected in the manner as referred to in Article 51 of the UUJN, it is first necessary to remember that there are 2 (two) types of notarial deeds, namely party deeds and relaas deeds. A party deed is a deed "made before" a notary, while a relaas deed is a deed "made by" a notary. The two types of deeds have different characteristics. Therefore, the interpretation and limitations of the application of the correction method as referred to in Article 51 of the UUJN also depend on the type of deed.

A party deed or a party deed is a type of notarial deed which contains matters explained or told by another party to a notary as an authentic deed maker. The other party intentionally comes before a notary and gives a statement or performs a legal action before a notary, so that the statement or action is confirmed by the notary in an authentic deed. Thus, in a party deed, authentically the statements of the persons acting as parties to the deed as well as the statement of the notary himself which states that the people present have stated certain wishes, as stated in the deed. ${ }^{16}$

\footnotetext{
14 Mochtar Kusumaatmadja, Hukum, Masyarakat dan Pembinaan Hukum Nasional, Binacipta, Jakarta, 2003, p. 22.

${ }^{15}$ M. Ali Boediarti, Kompilasi Kaidah Hukum Acara Perdata, Swa Justitia, Jakarta, 2005, p.152

${ }^{16}$ G.H.S. Lumban Tobing, Peraturan Jabatan Notaris, Erlangga, Jakarta, 1980, p. 44
} 
Basically, corrections that can be made to typos in the Limited Liability Company (CV) are casuistic in nature. This means that an attempt at correction cannot always be applied to all typos. The notary must first look at the part of the deed where the typo occurred and the extent to which the error caused a difference from what should have been written.

Efforts to Correct a Deed in an Official Deed/Relationship Deed is a type of notarial deed that contains an authentic description of an action taken or a situation seen or witnessed by the notary himself in carrying out his office. In contrast to the party deed which must be signed by the appearer in order to be called an authentic deed, in a relaas deed it does not matter whether the appearers sign the deed, as long as the notary in the deed mentions why the appearers did not sign it. One example of a relaas deed is the Deed of Minutes of the General Meeting of Shareholders of a Limited Liability Company.

As in the party deed, in the relaas deed, typos can also occur. For example, in a GMS whose meeting agenda is "approval to the Board of Directors to lend money to the bank" it was decided that the shareholders decided to give approval to the Board of Directors to borrow money from the bank in the amount of IDR 10,000,000,000 (ten billion rupiah). However, due to a notary's error, the Deed of Minutes of the relevant GMS stated that the loan amount was IDR 1,000,000,000 (one billion rupiah). Thus, there is a difference between the facts that occurred during the GMS and what was stated in the notarial deed.

If there is a typo in the results of the GMS decision in the Deed of Minutes of the GMS, the first effort that must be made by the notary is to urge the shareholders to come back before the notary to make a GMS. In the GMS, the shareholders can rectify the GMS decision that is typo.

If it turns out that it is not possible to bring back all shareholders before a notary, then a decision can be made outside the GMS, as referred to in Article 91 of Act No. 40 of 2007 concerning Limited Liability Companies (hereinafter referred to as UUPT). Article 91 of the Company Law stipulates that shareholders can also make binding decisions outside the GMS on condition that all shareholders with voting rights agree in writing by signing the proposal in question. This is in practice known as circular resolution.

If the decision making outside the GMS (circular decision) cannot be made, the notary can make another effort, namely by making a Deed of Minutes of Correction as referred to in Article 51 of the UUJN.

A Deed of Minutes of Correction can be made for a relaas deed in which there is a typo, even though the typo is substantive. This is related to the nature of the relaas deed. 
Basically, a relaas deed is a type of notarial deed that contains things witnessed by a notary. In a GMS, a notary is present and witnesses the decisions made by the shareholders and then puts them in the Deed of Minutes of the GMS. It is the notary who must ensure that the things contained in the deed are in accordance with the reality that is witnessed and experienced. Even if the appearers at the GMS refuse to sign or have left at the closing of the deed so that they cannot sign the minutes of the deed, the Deed of Minutes of the GMS is still recognized as an authentic deed.

This means that if there is a typo in a relaas deed, the notary concerned is the person authorized to correct it. Even if the typo concerns a substantive matter, the notary is still authorized to correct it because the relaas deed is a deed made by a notary, not made by the appearers before a notary.

\section{Closing}

Role investigator against the Notary who made a copy of the deed, Investigators, Public Prosecutors, and Judges are only allowed to take photocopies of the minutes of deed and/or letters attached to the minutes of deed or notary protocol in the notary's depository, as long as it is for the purposes of the judicial process and has obtained the approval of the Notary Honorary Council; Summons of a notary by investigators, public prosecutors or judges to attend the examination of a case, whether civil, criminal or state administration/administration that are not related to the deed made or the protocol of the notary in the notary's depository, does not require approval from the Notary Honorary Council; In the sense of a notary as stated in Article 66 of Act No. 2 of 2014 concerning Notary Positions, including Temporary Notary Officials, Substitute Notaries, and Special Substitute Notaries. Efforts that can be made by a notary in the event of a typo contained in the minutes of deed whose copies have been issued are basically casuistic in nature. However, in general the efforts that a notary can take depend on the type of deed and the location of the typo. If in the party deed/deed of parties, for example the Deed of Establishment of a Limited Liability Company (CV), there is a typo: In the notary's statement at the beginning of the deed; On the identity of the appearer; In the contents of the deed which is the will of the appearer. If in the relaas deed, for example the Deed of Minutes of the General Meeting of Shareholders (GMS), there is a typo, then the efforts that the notary can take are: Calling on the shareholders to correct the typo in the GMS resolution, either by holding another GMS or by making circular decisions and Make a Deed of Minutes of Correction and carry out the procedures as referred to in Article 51 of the UUJN. 


\section{References}

Journals:

[1] A Chuasanga, Ong Argo Victoria. (2019). Legal Principles Under Criminal Law in Indonesia Dan Thailand, Jurnal Daulat Hukum, Vol 2, No 1 (2019) http://jurnal.unissula.ac.id/index.php/RH/article/view/4218

[2] Deen, Thaufiq., Ong Argo Victoria \& Sumain. (2018). Public Notary Services In Malaysia. JURNAL AKTA: Vol. 5, No. 4, 1017-1026. Retrieved from http://jurnal.unissula.ac.id/index.php/akta/article/view/4135

[3] Ong Argo Victoria, (2018) Waqf Al-Nuqūd In Indonesia (In Law Perspective), Jurnal Pembaharuan Hukum Vol 5, No 1 Universitas Sultan Agung, http://jurnal.unissula.ac.id/index.php/PH/article/view/2999

[4] Sukarmi, S., \& Victoria, A. (2018). Cash Waqf in Sustaining Of Indonesian Society "In Legal \&amp; Economic Perspective". AL-ITQAN: JOURNAL OF ISLAMIC SCIENCES AND COMPARATIVE STUDIES, 2(1), 83-97. https://doi.org/10.31436/al-itqan.v2i1.43

Books:

[1] Kohar, A., (1983), Notaris Dalam Praktek Hukum, Bandung: Alumni.

[2] Anshori, Abdul Ghofur, (2009), Lembaga Kenotariatan Indonesia Perspektif Hukum dan Etika, Yogyakarta: UII Press.

[3] Tobing, G.H.S. Lumban, (1980) Peraturan Jabatan Notaris, Jakarta: Erlangga.

[4] (1999), Peraturan Jabatan Notaris, Jakarta:

\section{Erlangga.}

[5] Salim, H. \& Abdullah, H., (2007), Perancangan dan MOU, Jakarta: Sinar Grafika.

[6] Boediarti, M. Ali, (2005), Kompilasi Kaidah Hukum Acara Perdata, Jakarta: Swa Justitia

[7] Kusumaatmadja, Mochtar, (2003), Hukum, Masyarakat dan Pembinaan Hukum Nasional, Jakarta: Binacipta.

[8] Abdulkadir, Muhammad, (2004), Hukum dan Penelitian Hukum, Bandung: Citra Aditya Bakti.

[9] Nico, (2003), Tanggung Jawab Notaris Selaku Pejabat Umum, Yogyakarta: Centre for Documentation and Studies Bussiness Law.

[10] Notodisorjo, R. Soegondo, (1993), Hukum Notariat di Indonesia (Suatu Penjelasan), Jakarta: Raja Grafindo Persada.

[11] Kie, Tan Thong, (2000), Studi Notariat dan Serba-serbi Praktek Notaris, Buku 1, Jakarta: Ichtiar Baru Van Hoeve.

[12] Situmorang, Viktor M. dan Sitanggang, Cormentya, (1993), Grosse Akta dalam Pembukuan dan Eksekusi, Jakarta: Rineka Cipta. 
Regulation:

[1] Act No. 2 of 2014 concerning Amendments to Act No. 30 of 2004 concerning the Position of Notary

[2] Civil Code

[3] Constitution of 1945 the Republic of Indonesia

[4] Decree of the Minister of Justice of the Republic of Indonesia Number M.13-HT.03.10 of 1983 concerning the Development of Notaries

[5] Decree of the Minister of Law and Human Rights of the Republic of Indonesia Number M01.HT.03.01 of 2003 concerning Notary 